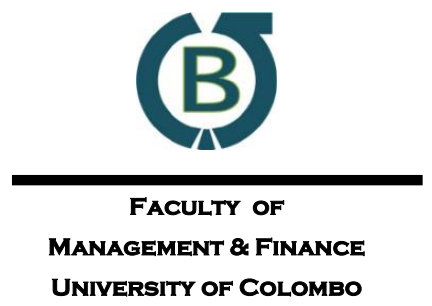

Colombo

Business

Journal

UNIVERSITY OF COLOMBO

INTERNATIONAL JOURNAL OF

THEORY \& PRACTICE

Vol. 10, No. 02, December, 2019

\title{
How Does Bank Competition Affect Systemic Banking Crises?
}

\author{
Samangi Bandaranayake \\ Department of Finance, University of Colombo, Sri Lanka
}

\begin{abstract}
Literature present conflicting views on the effect of bank competition on financial stability. Some argue that competition increases adverse shocks in the financial system while others argue that it reduces the likelihood of such events. The purpose of this study is to further examine this relationship using a more recent systemic banking crises database of Laeven and Valencia (2018). There are 61 countries which had experienced systemic crises during 19962017. This study used Lerner index and Boone indicator as proxy measures of competition and three estimation techniques to estimate the relationship. The results indicate that the effect of competition on financial stability varies with estimation techniques and proxy measures of competition and stability. Lerner index indicates that competition increases financial instability while Boone indicator shows the opposite. Thus, this study concludes with mixed evidence on the relationship between bank competition and financial stability.
\end{abstract}

Keywords: Bank Competition, Boone Indicator, Lerner Index, Systemic Banking Crises

Received:

29 April 2019
Accepted revised version:

16 September 2019
Published:

31 December 2019

Suggested citation: Bandaranayake, S. (2019). How does bank competition affect systemic banking crises? Colombo Business Journal. (10)2, 1-24

DOI: http://doi.org/10.4038/cbj.v10i2.49

(C) 2019 The Authors. This work is licenced under a Creative Commons Attribution 4.0 International Licence which permits unrestricted use, distribution, and reproduction in any medium, provided the original work is properly cited.

$\bowtie$ samangibandaranayake@dfn.cmb.ac.lk: (iD) https://orcid.org/0000-0002-7061-7159 


\section{Introduction}

The effect of bank competition on financial system stability has been a controversial issue among researchers and policymakers. Allen and Gale (2004), Keeley (1990), and Marcus (1984) propose that bank competition increases instability in the financial system. Boyd and De Nicolo (2005) introduce an opposing view to find an inverse relationship between bank competition vulnerability of the financial system to adverse shocks. Zigraiova and Havranek (2016) address this controversial issue using a meta-analysis. They collect 31 prior studies on bank competition and financial stability and find conflicting evidence mainly due to issues with selection of countries for the study, different time windows of sampling, use of different proxy measures for competition and stability, and due to heterogeneity in estimation methods. It is important to empirically investigate the findings of Zigraiova and Havranek (2016) to confirm the reasons for this debatable issue and to suggest potential regulatory actions to maintain financial stability that can be implemented across countries. Bandaranayake, Das, and Reed (2019) empirically examined the findings of Zigraiova and Havranek (2016) using the systemic banking crises database of Laeven and Valencia (2012) and did not find results supporting either the "competition-stability" view or "competition-fragility" view. Therefore, the purpose of this study is to further examine the findings of previous authors using a different sample of countries, in a different sample period, using several proxy measures of bank competition and financial stability, and with various estimation techniques.

This study uses the updated global database on systemic banking crises of Laeven and Valencia (2018). Results of this empirical investigation confirms the findings of Zigraiova and Havranek (2016). The effect of bank competition on financial stability varies with the proxy measures of competition and stability. Furthermore, different estimation models suggest different relationships.

The remainder of the paper is organized as follows: Firstly, it presents a review of related literature. This is followed by an explanation of competition measures and stability measures. Then methods of estimation are presented, after which data and variables of the study are presented. The results and findings of the study are discussed next, and finally, a summary of the conclusions is presented.

\section{Literature Review}

\section{Competition-Fragility Hypothesis}

In 1970s and 1980s, banking sector regulations were relaxed in many countries of the world. Financial sector liberalization encouraged competition in banking. In addition, technological changes and developments in money markets also contributed 
to increasing competition among banks. Resultant increased risk taking increased number of bank failures (Keeley, 1990). Based on this observation, several authors introduced the "competition-fragility" hypothesis (Allen \& Gale, 2004; Keeley, 1990; Marcus, 1984). They found that an increase in competition tend to reduce the charter value of a bank and increase the risk of bank failure. Moreover, a banking system with few large institutions is more stable compared to a competitive banking system because in the earlier scenario, banks have the opportunity to generate more profits, to diversify business, and to monitor operations. This would make banks more resilient to external threats (Beck, 2008; Berger, Demirgüç-Kunt, Levine, \& Haubrich, 2004).

Many empirical studies find evidence to support the 'competition-fragility' hypothesis (Agoraki, Delis, \& Pasiouras, 2011; Beck, De Jonghe, \& Schepens, 2013; Berger, Klapper, \& Turk-Ariss, 2009; Fu, Lin, \& Molyneux, 2014; Yeyati \& Micco, 2007). These studies present their results based on various proxy measures of stability and competition. (A full discussion of measures of competition and stability will be presented later.) Tabak, Fazio, and Cajueiro (2012) use Boone indicator as the competition measure and Z-score as the stability measure. Many studies considered Lerner index as the measure of competition and Z-score as the measure of stability (Agoraki et al., 2011; Beck et al., 2013; Fernandez \& Garza-Garciab, 2012; Fu et al., 2014). Yeyati and Micco (2007) present their evidence based on H-statistic as the measure of competition and Z-score as the stability measure.

\section{Competition-Stability Hypothesis}

Boyd and De Nicolo (2005) revisit the view of Keeley (1990) and introduce an opposing theoretical explanation known as 'competition-stability' hypothesis. According to their interpretation, banks compete in both deposit and lending markets. In a less competitive market, banks pay low deposit rates and charge high interest from borrowers, which allow them to have a greater spread in the interest rates. At the same time, high loan rates increase the cost of borrowings which leads to a decline the profit margin of borrowers. That results in an increase of the default probability of loan repayments and increase in the non-performing loan ratio of banks. Boyd and De Nicolo (2005) explain that in a competitive banking system, banks offer low borrowing rates to their clients and it reciprocally contributes to reducing the level of credit risk. Their theoretical view suggests that the competition in the banking system promotes stability in the financial system. Caminal and Matutes (2002) also support their view and explain that monopolists accept more risk and there are high tendencies to go bankrupt compared to competitive banks. Increasing competition reduces the power of individual players and it contributes to reduce the risk of bank failure. 
Similar to 'competition-fragility' view, empirical studies support the 'competition-stability' hypothesis as well by using different proxy measures for competition and stability (Amidu \& Wolfe, 2013; Goetz, 2016; Jeon \& Lim, 2013; Liu, Molyneux, \& Wilson, 2013; Schaeck \& Cihak, 2008, 2014; Schaeck, Cihak, \& Wolfe, 2009). The estimation results of Schaeck et al. (2009) are based on the Hstatistic and a dummy variable to represent the occurrence of a crisis. Results find that there is a positive relationship between competition and stability. They explain that time-to-crisis increase with an increase in competition. Schaeck and Cihak (2008, 2014) assess the relationship between Boone indicator and Z-score and support the view that competitive banks are efficient and stable. Amidu and Wolfe (2013) use Lerner index and $\mathrm{H}$-statistic as competition measures and $\mathrm{Z}$-score, non-performing loans, bank profitability as stability measures. Their findings confirm that more competition is associated with greater stability.

In summary, the 'competition-stability' hypothesis and the 'competitionfragility' hypothesis present different theoretical arguments about the effect of bank competition on financial stability. In addition to that, empirical investigations also arrive at different conclusions.

\section{Measures of Bank Competition and Financial Stability}

There is no consensus regarding the best measure to capture the competition effect. The previous section presents evidence for use of various proxy measures for competition and stability in empirical literature. Bikker and Haaf (2000) explain two categories of competition measures. The first category uses the structural measure as measures of competition. Bank concentration ratio and Herfindahl-Hirschman index (HHI) are the common structural measures. The bank concentration ratio is the total assets of three or five largest banks as a percentage of total assets of the entire banking system. The HHI is the sum of the squared market share of each bank. However, empirical literature finds that the concentration ratio and $\mathrm{HHI}$ are poor proxies for bank competition (Claessens \& Laeven, 2004; Schaeck et al., 2009). The second category of competition measures comprises non-structural measures. The common non-structural measures are $\mathrm{H}$-statistic, Lerner index, and Boone indicator. These measures capture different characteristics of the banking system (Leon, 2015). This study considers three-bank concentration ratio as the structural measure of bank competition. The country level H-statistic data are available from year 2010. Due to that data limitation, Lerner index and Boone indicator are used to capture the nonstructural measures of bank competition. 


\section{Lerner Index}

Lerner index captures the market power of the bank. It compares the bank's output price with its related marginal costs. The marginal cost of a bank is estimated based on a translog cost function (Spierdijk \& Zaouras, 2016). The zero value reflects the competitive behaviour of banks and a positive value reflects less competitive behaviour. A larger value indicates a wider gap between output price and marginal costs and greater monopoly power. Likewise, a smaller value indicates more competition.

Lerner $_{i t}=\frac{\left(P_{i t}-M C_{i t}\right)}{P_{i t}}$,

In Equation (1), $P_{i t}$ is the ratio of total revenue to total assets and $M C_{i t}$ is the marginal cost. The subscripts $i$ and $t$ denote each country and year respectively.

Lerner index is a flexible measure and it allows the measurement of market power separately for individual banks. More importantly, it can be calculated with a limited number of observations, which is particularly important when the data availability is limited. Conversely, there are limitations of the Lerner index. Lerner index is a static measure based on the price of the bank (Leon, 2015). Oliver, Fumás, and Saurina (2006) point out that market power varies across loan products and overall Lerner index does not capture the real power of the market.

\section{Boone Indicator}

Boone (2008) introduces a new measure of competition. It considers the impact of efficiency on performance. Boone (2008) presents the new measure based on two assumptions. Firstly, banks are producing close substitutes. Secondly, there are fewer barriers to entry. When there is an increase in the product substitution, consumers will obtain the service from the bank that charges less for their service. An efficient bank generates high profits when its marginal cost is low which will therefore have a more negative Boone indicator (Tabak et al., 2012). The Equation (2) shows the estimation of the Boone indicator $(\beta)$. Profits increase for banks with lower marginal cost $(\beta<0)$. Hence, an increase in competition improves the profits of an efficient bank relative to a less efficient bank (Schaeck \& Cihak, 2010).

$\ln \pi_{i t}=\alpha+\beta \ln \left(C_{i t}\right)$,

where $\pi_{i t}$ indicates return on assets of country $i$ at time $t, \beta$ is referred as the Boone indicator and $C$ is the cost. 
Literature considers either the average or marginal cost to estimate the Boone indicator. Schaeck and Cihak (2014) use an average cost to estimate the Boone indicator. Tabak et al. (2012), Van Leuvensteijn, Bikker, van Rixtel, and Sørensen (2011), use marginal cost to estimate the Boone indicator. This study uses the Boone indicator calculated by the Global Financial Development Database (GFDD) and it follows the estimation method based on marginal cost. The main advantage of the Boone indicator is, that it estimates the relationship between costs and profits in a dynamic market. It only requires information about profits (or market share) and cost. It is a non-price measure and does not require a static price as required by Lerner index. However, the main limitation of the Boone indicator is that it assumes that the efficiency gains of banks are immediately translated into lower costs or higher profits in the short term (Leon, 2015).

\section{Z-Score as a Measure of Stability}

Z-score is a widely used accounting-based risk measure and is computed using data from individual banks. It compares the capital buffer and returns of the bank with the volatility of returns and interprets it as the inverse probability of default (Boyd, Graham, \& Hewitt, 1993; Boyd \& Runkle, 1993). A higher Z-score value indicates a lower probability of default and provides more stability. It is estimated as follows:

$Z-$ score $_{i t}=\frac{\left(R_{0} A_{i t}+\frac{\text { Equity }_{i t}}{\text { Assets }_{i t}}\right)}{\operatorname{SDROA}_{i t}}$

where $R O A_{i t}$ indicates the return on assets of the country $i$ at time $t$, Equity $y_{i t}$ is the aggregated equity level of banks in the country $i$ at time $t$, Assets $_{i t}$ is the total assets held by banks of the country $i$ at time $t$, and $S D R O A_{i t}$ is the standard deviation of $R O A$ or the volatility of return. GFDD uses country-level aggregate figures of ROA, equity, and assets calculated from underlying bank-by-bank data from Bankscope database.

\section{Banking Crisis as a Measure of Stability}

This is a dummy variable that takes the value one for a given country in a given year if an event meets two conditions (Laeven \& Valencia, 2012, 2018) or zero otherwise. According to Laeven and Valencia (2012) the first year in which both criteria are met, is the year when the crisis become systemic. The two conditions are as follows: 
1. "Significant signs of financial distress in the banking system (as indicated by significant bank runs, losses in the banking system, and/or bank liquidations).

A significant sign of financial distress is when there are large number of defaults in a country's corporate and financial sectors and corporate firms experience difficulties repaying contracts on time. Due to that there is an increase in the share of non-performing loans. Furthermore, there may be depositor runs on banks, decrease in asset prices, increase in real interest rates, and reversal of capital flows to the financial sector (Laeven \& Valencia, 2008).

2. Significant banking policy intervention measures in response to significant losses in the banking system".

Laeven and Valencia (2012) consider policy interventions are significant if at least three of the following measures have been used in response to losses in the banking system:

i. extensive liquidity support (5\% of deposits and liabilities to nonresidents)

ii. bank restructuring gross costs (at least 3\% of GDP)

iii. significant bank nationalizations

iv. significant guarantees put in place

v. significant asset purchases (at least 5\% of GDP)

vi. deposit freezes and/or bank holidays.

\section{Methods of Estimation}

Zigraiova and Havranek (2016) find that estimation method is one of the reasons for conflicting findings on bank competition and financial stability. This study utilizes three estimation models to validate the findings of Zigraiova and Havranek (2016). Literature commonly uses duration analysis and logistic probability analysis (Beck, Demirgüç-Kunt, \& Levine, 2006; Demirgüç-Kunt \& Detragiache, 1998, 2005; Diallo, 2015; Schaeck et al., 2009). In addition to those two estimation methods, fractional logistic estimation is also considered in this study since one of the selected dependent variables is a fractional variable. Bandaranayake et al. (2019) use Z-score as the dependent variable and previous study estimate the results using fractional logistic estimation. This study applies the same approach.

Diallo (2015), Schaeck et al. (2009) use duration analysis and this study follows the same approach. The duration model measures the time to transition from a sound 
banking system to the occurrence of a systemic crisis. Any variable that is positively associated with stability will have a positive coefficient in the duration analysis, and this (a positive coefficient) suggests a longer time to a systemic crisis (Bandaranayake et al., 2019). The survival function of a banking system is:

$S(t)=\operatorname{Pr}(T \geq t)$

which equals one minus cumulative distribution function of $T$. To calculate the sudden rate of failure, that is, the average probability of failing per unit time period over the interval $t$ until $t+h$, a hazard function is defined as:

$\lambda(t)=\lim _{h \downarrow 0} \frac{P\{t \leq T(t+h \mid T \geq t\}}{h}=\frac{-d \log S(t)}{d(t)}=\frac{f(t)}{S(t)}$.

The proportional hazard function is:

$\lambda(t, X(t), \beta)=\lim _{h \downarrow 0} \frac{P\{t \leq T \leq t+h \mid T \geq t, X(t), \beta\}}{h}=\lambda_{0}(t) \exp \left(\beta^{\prime} X_{t}\right)$,

where $X_{t}$ denotes the time-varying explanatory variables, $\beta$ is the parameter vector, $\lambda_{0}(t)$ is the baseline hazard function, and $\exp \left(\beta^{\prime} X_{t}\right)$ is a convenient interpretation of the coefficients due to its non-negativity. $\lambda_{0}(t)$ is the baseline hazard rate and it determines the shape of the hazard function with respect to time. The standard errors are corrected for heteroskedasticity and estimate the duration models based on the exponential distribution. It assumes a constant hazard rate over time (Schaeck et al., 2009).

Logit estimation is also widely used in the literature to estimate the probability of experiencing a banking crisis (Beck et al., 2006; Demirgüç-Kunt \& Detragiache, 1998, 2005; Diallo, 2015). In the logit model, any variable that positively contributes to stability will have a negative coefficient, as it explains an increase in a variable associated with a lower probability of a crisis (Bandaranayake et al., 2019).

$L n L=\sum_{t=1}^{T} \sum_{i=1}^{n}\left\{\operatorname{Pr}(i, t) \ln \left[F\left(\beta^{\prime} X(i, t)\right)\right]+(1-\operatorname{Pr}(i, t)) \ln \left[1-F\left(\beta^{\prime} X(i, t)\right)\right]\right\}$

where $P(i, t)$ is a dummy variable that takes on the value 1 when a systemic banking crisis is observed in country $i$ at time $t$, and 0 otherwise. The parameter $\beta$ is a vector of $n$ unknown coefficients, the explanatory variables are denoted by $X(i, t)$, and $F$ is the cumulative probability distribution function. 
Z-score is a fractional variable and it is the inverse of probabilities of default. It is restricted to the interval between 0 and 1. Papke and Wooldridge (1996) developed a fractional logistic estimation method for estimation models with the fractional dependent variable. Therefore, the fractional logistic estimation procedure is used to examine the effect of bank competition on stability when the dependent variable is the Z-score.

The main assumption in the fractional logistic estimation models is,

$$
E(Y \mid X)=G\left(X^{\prime} \beta\right)=1 /\left[1+\exp \left(-X^{\prime} \beta\right)\right]
$$

The predicted values of $Y$ lie in the interval $(0,1), G($.$) is cumulative distribution$ function and $X$ is observable. The fractional logit likelihood function is that,

$$
F(Y)=G\left(X^{\prime} \beta\right)^{Y} *\left(1-G\left(X^{\prime} \beta\right)^{1-Y} \text { for } 1 \geq Y \geq 0\right.
$$

\section{Data and Variables of the Study}

This study uses systemic banking crises and the country level Z-score as proxy measures of stability. The Boone indicator and Lerner index are considered as proxy measures of bank competition. Bandaranayake et al. (2019), Schaeck et al. (2009) control for macroeconomic environment, legal origin of countries, and for economic development when examining the relationship between bank competition and financial stability. This study considers same control variables to validate the results of the previous two studies. Therefore, the empirical analysis considers lagged GDP growth, inflation, real interest rate, terms of trade, real credit growth, and a variable for "moral hazard" associated with generous deposit insurance as macroeconomic determinants of financial stability. A set of dummy variables incorporated to control for British, German, French, Scandinavian, and other legal origins of countries ${ }^{1}$. Finally, a set of regional dummy variables are included for Group of ten (G10), African, Latin American, and other regions as general controls for economic development.

Country level Z-score, Boone indicator, Lerner index, and three-bank concentration ratio are collected from GFDD. Boone indicator and Lerner index data are available only after year 1996 . Therefore, the empirical analysis limits its sample period from 1996 to 2017.

\footnotetext{
${ }^{1}$ Data is collected from La-Porta, Lopez-de-Silanes, and Shleifer (1998)
} 
This study collects systemic banking crises data from Laeven and Valencia (2018). The crisis variable is a dummy variable that takes on the value one if a systemic banking crisis occurred in the particular year or zero otherwise. There are 61 countries that had experienced a single or multiple systemic crises events during the period 1996-2017 and there are 51 crisis-year observations in the selected sample. The number of crises counts for the duration model and logit model are different due to the different set up of data.

Descriptive statistics for variables are presented in Table $1^{2}$. A detailed description of variables is given in the Appendix 1. Appendix 2 presents the pairwise correlations of country level variables. Pairwise correlations suggest that there are low correlations among all the selected variables. The pairwise correlation of Lerner index and Boone indicator shows a very low positive correlation and it is statistically significant at $5 \%$. Those two proxy measures of bank competition indicate a positive correlation with three-bank concentration ratio.

Table 1: Descriptive Statistics

\begin{tabular}{lrrrr}
\hline & Mean & $\begin{array}{c}\text { Standard } \\
\text { deviation }\end{array}$ & Minimum & Maximum \\
\hline GDP growth & 3.6948 & 3.9685 & -17.6690 & 33.6294 \\
Real interest rate & 10.3595 & 49.1085 & -26.7203 & 33.6294 \\
Inflation & 9.2446 & 82.9114 & -9.5588 & 2630.1230 \\
Terms of trade & 0.6271 & 8.5932 & -43.4182 & 67.7966 \\
Credit growth & 0.6877 & 0.6265 & 0.0021 & 4.4629 \\
Moral hazard index & -0.0280 & 2.8200 & -11.8615 & 4.6184 \\
German legal origin & 0.2266 & 0.4188 & 0 & 1 \\
British legal origin & 0.1579 & 0.3648 & 0 & 1 \\
French legal origin & 0.2614 & 0.4396 & 0 & 1 \\
Scandinavian legal origin & 0.0357 & 0.1856 & 0 & 1 \\
Other legal origin & 0.3185 & 0.4661 & 0 & \\
\hline
\end{tabular}

${ }^{2}$ Data and Codes to reproduce the results of the paper are available on https://dataverse.harvard.edu/dataset.xhtml?persistentId=doi:10.7910/DVN/N2WDDA 


\begin{tabular}{lcccr}
\hline & Mean & $\begin{array}{r}\text { Standard } \\
\text { deviation }\end{array}$ & Minimum & Maximum \\
\hline G10 & 0.1677 & 0.3738 & 0 & 1 \\
African region & 0.1276 & 0.3338 & 0 & 1 \\
Latin American region & 0.0972 & 0.2964 & 0 & 1 \\
Other regions & 0.6075 & 0.4885 & -1.1368 & 0.8212 \\
Lerner index & 0.2387 & 0.1275 & -281.2470 & 11.3449 \\
Boone indicator & -1.1600 & 12.8262 & 0.2019 & 1 \\
Concentration ratio & 0.6523 & 0.1969 & 0.0048 & 0.4695 \\
Z-score & 0.1152 & 0.0675 & & 1 \\
\hline
\end{tabular}

\section{Empirical Results}

Table 2 presents regression results using duration model. A positive sign in duration model indicates increased time-to-crisis or increased stability. Column (1) reports results of estimating the model with control variables and Lerner index to represent the competition. Column (2) adds the concentration ratio to the same specification in Column (1). Column (3) repeats the same specification as Column (1) and it adds Boone indicator as the bank competition measure instead of Lerner index. Column (4) adds the concentration ratio to the same specification in Column (3). Similarly, in Table 3 Columns (1) through (4) do the same for logit model. A positive sign for the coefficient in logit model indicates a greater probability of experiencing a crisis or increased fragility. Table 4 uses the country level Z-score as the dependent variable and reports results of fractional logistic model. Column (1) through (4) in Table 4 also follows the same specification as Table 2.

In Table 2, Lerner index enters Specifications (1) and (2) positively and results are not statistically significant. The Boone indicator enters Specifications (3) and (4) negatively and significant at $5 \%$ level. This indicates that time-to-crisis increases as the Boone indicator decreases which is supportive of the 'competition-stability' view. Schaeck and Cihak (2014) find that bank competition enhances financial stability based on the Boone indicator and the results of Table 2 confirm the same relationship. Furthermore, it approves that promoting bank competition for financial stability drives inefficient players from the market (Berger et al., 2009; Schaeck \& Cihak, 
2014; Schaeck et al., 2009). Concentration enters Specifications (2) and (4) positively and results are statistically insignificant. Literature find that that bank concentration leads to financial stability and results do not support the finding of Beck, DemirgüçKunt, and Levine (2003), Liu, Molyneux, and Nguyen (2012), Schaeck et al. (2009). Terms of trade and credit growth are the macroeconomic variables that predict statistically significant results in all specifications. Both variables indicate that the increase in terms of trade and increase in credit growth decrease the survival time and occurrence of a systemic crisis. Increase in terms of trade implies heavy dependency on primary commodity exports (Schaeck et al., 2009). Increase in credit growth reflects the increasing trend of providing credit facilities to the domestic sector of the respective country. Scandinavian legal origin enters positively and significantly in all four columns which suggest that a longer time-to-crisis in countries with Scandinavian legal origins compared to countries with any other legal origin.

Table 2: Bank Competition and Timing of Systemic Banking Crisis

\begin{tabular}{lrrrr}
\hline & & \multicolumn{2}{c}{ Duration Model } & \\
& Specification & Specification & Specification & Specification \\
& $(\mathbf{1})$ & $(\mathbf{2})$ & $\mathbf{( 3 )}$ & $\mathbf{( 4 )}$ \\
\hline GDP growth & 0.0606 & 0.0577 & 0.0405 & 0.0274 \\
& $(0.0715)$ & $(0.0668)$ & $(0.0581)$ & $(0.0593)$ \\
$\begin{array}{l}\text { Real interest } \\
\text { rate }\end{array}$ & -0.0115 & -0.0121 & -0.0078 & -0.0148 \\
Inflation & $(0.0217)$ & $(0.0220)$ & $(0.0074)$ & $(0.0119)$ \\
& 0.0093 & 0.0106 & 0.0212 & 0.0197 \\
Terms of trade & $(0.0398)$ & $(0.0385)$ & $(0.0379)$ & $(0.560)$ \\
& $-0.0449 * * *$ & $-0.0446 * * *$ & $-0.0468 * * *$ & $-0.0462 * * *$ \\
Credit growth & $(0.0161)$ & $(0.0163)$ & $(0.0156)$ & $(0.1565)$ \\
& $-0.3861 *$ & $-0.3850 *$ & $-0.5703 * *$ & $-0.6218^{* *}$ \\
$\begin{array}{l}\text { Moral hazard } \\
\text { index }\end{array}$ & $(0.2152)$ & $(0.2129)$ & $(0.2677)$ & $(0.3087)$ \\
$\begin{array}{l}\text { German legal } \\
\text { origin }\end{array}$ & 0.0873 & $0.1068 *$ & 0.0929 & $0.1273 *$ \\
$\begin{array}{l}\text { British legal } \\
\text { origin }\end{array}$ & $(0.0599)$ & $(0.0611)$ & $(0.0707)$ & $(0.0710)$ \\
\hline & 1.2327 & 1.1733 & 1.1800 & 1.2258 \\
& $(0.9693)$ & $(0.9288)$ & $(0.9740)$ & $(0.9953)$ \\
& $1.3384 *$ & $1.3695 *$ & 1.1312 & 1.3749 \\
\hline
\end{tabular}




\begin{tabular}{|c|c|c|c|c|}
\hline & \multicolumn{4}{|c|}{ Duration Model } \\
\hline & Specification & Specification & Specification & Specification \\
\hline & (1) & (2) & (3) & (4) \\
\hline & $(0.7333)$ & $(0.7710)$ & $(0.8918)$ & $(0.9722)$ \\
\hline \multirow{2}{*}{$\begin{array}{l}\text { French legal } \\
\text { origin }\end{array}$} & $1.3456 * *$ & $1.3614 * *$ & 0.8444 & 0.8930 \\
\hline & $(0.6855)$ & $(0.6944)$ & $(0.6668)$ & $(0.6490)$ \\
\hline \multirow{2}{*}{$\begin{array}{l}\text { Scandinavian } \\
\text { legal origin }\end{array}$} & $14.2780 * * *$ & $14.0501 * * *$ & $15.0712 * * *$ & $14.4782 * * *$ \\
\hline & (1.1702) & $(1.1240)$ & (1.1612) & (1.0954) \\
\hline \multirow[t]{2}{*}{ African region } & 1.3292 & 1.3520 & 1.3715 & 1.1261 \\
\hline & $(1.4668)$ & $(1.4821)$ & (1.2069) & (1.2624) \\
\hline \multirow{2}{*}{$\begin{array}{l}\text { Latin American } \\
\text { region }\end{array}$} & 1.1171 & 1.2309 & 1.1767 & 1.7177 \\
\hline & $(0.9043)$ & $(0.9504)$ & (0.9008) & $(1.1820)$ \\
\hline \multirow[t]{2}{*}{ Other regions } & 0.9479 & 0.9161 & 0.8224 & 07880 \\
\hline & $(0.6302)$ & $(0.6457)$ & $(0.5211)$ & $(0.6420)$ \\
\hline \multirow[t]{2}{*}{ Lerner index } & 0.1510 & 0.1359 & - & \\
\hline & $(1.4185)$ & $(1.4653)$ & & \\
\hline \multirow[t]{2}{*}{ Boone indicator } & - & - & $-0.2189 * *$ & $-0.1970 * *$ \\
\hline & & & (0.9999) & $(0.1007)$ \\
\hline \multirow[t]{2}{*}{ Concentration } & - & 0.5651 & - & 1.8114 \\
\hline & & (1.1086) & & (1.3827) \\
\hline Observations & 430 & 421 & 478 & 468 \\
\hline
\end{tabular}

Notes: 1. The dependent variable in the estimation Specifications (1) to (4) is log of time-to-crisis. If a crisis runs over several years, the first year is considered and following years are deleted from the dataset. If a country experienced multiple crisis events, subsequent crises are included.

2. The numbers in parentheses below estimated coefficients are cluster robust standard errors, clustered on country.

3. *, ** and $* * *$ denote significance levels $p<0.01, p<0.05$ and $p<0.1$, respectively.

The results from duration model validated by the logit model results in Table 3. The Lerner index has a negative sign and is statistically significant at 5\% level. It indicates that crisis probability increases with more competitive banking systems. One standard deviation increase in the Lerner index (0.1275) leads to an increase in the probability of systemic crisis by $2.78 \%\left(0.1275^{*}-0.02179=-0.0278\right)^{3}$. This is in

\footnotetext{
${ }^{3}$ The marginal effect measures the instantaneous rate of failure. It measures the impact change in Lerner index has on the probability of crisis occurring. The marginal effect of the coefficient
} 
line with the findings of (Agoraki et al., 2011; Diallo, 2015). The Boone indicator enters Specifications (3) and (4) positively and which are significant at $1 \%$ level. An increase of one standard deviation in the Boone indicator (12.8262) decreases crisis probability by $22.96 \%(12.8262 * 0.0179=0.2296)^{4}$. The findings based on Boone contradict with the results of Diallo (2015). These results indicate that the Lerner index contributes to 'competition-fragility' view and the Boone indicator supports the 'competition-stability' view. Among macroeconomic control variables, inflation and terms of trade are statistically significant in all specifications. A positive coefficient for inflation indicates that high inflation is a sign for occurrence of a systemic banking crisis. A negative coefficient for terms of trade implies that an increase in terms of trade leads to a reduction in the probability of a crisis.

Table 3: Bank Competition and Probability of Systemic Banking Crisis

\section{Logit Model}

Specification Specification Specification Specification

(1)

(2)

(3)

(4)

\begin{tabular}{lrrrr}
\hline GDP growth & 0.1362 & 0.1326 & 0.1130 & 0.1586 \\
& $(0.1313)$ & $(0.1276)$ & $(0.1034)$ & $(0.1063)$ \\
$\begin{array}{l}\text { Real interest } \\
\text { rate }\end{array}$ & 0.0233 & 0.0227 & 0.0213 & $0.0931 * * *$ \\
Inflation & $(0.0226)$ & $(0.0229)$ & $(0.0140)$ & $(0.0283)$ \\
& $0.0965^{* *}$ & $0.0934 * *$ & $0.0998 * *$ & $0.1449 * * *$ \\
Terms of trade & $(0.0444)$ & $(0.0443)$ & $(0.0475)$ & $(0.0531)$ \\
& $-0.1110^{* * *}$ & $-0.1125 * * *$ & $-0.1436 * * *$ & $-0.1481 * * *$ \\
Credit growth & $(0.0283)$ & $(0.0284)$ & $(0.0522)$ & $(0.0508)$ \\
& $1.0026 * * *$ & $1.0086 * * *$ & 0.6360 & 0.1933 \\
$\begin{array}{l}\text { Moral hazard } \\
\text { index }\end{array}$ & $(0.3643)$ & $(0.3800)$ & $(0.4861)$ & $(0.4833)$ \\
$\begin{array}{l}\text { German legal } \\
\text { origin }\end{array}$ & 0.0236 & 0.0066 & -0.1188 & -0.2547 \\
$\begin{array}{l}\text { British legal } \\
\text { origin }\end{array}$ & $(0.1359)$ & $(0.1629)$ & $(0.1298)$ & $(0.1710)$ \\
& 0.0164 & 0.2207 & -1.0807 & -0.7350 \\
\hline
\end{tabular}

of Lerner index from the logit model reported in Specification (1) is considered to calculate the effect and it is -0.2179 .

${ }^{4}$ The marginal effect of Boone indicator is 0.0179 . 
Logit Model

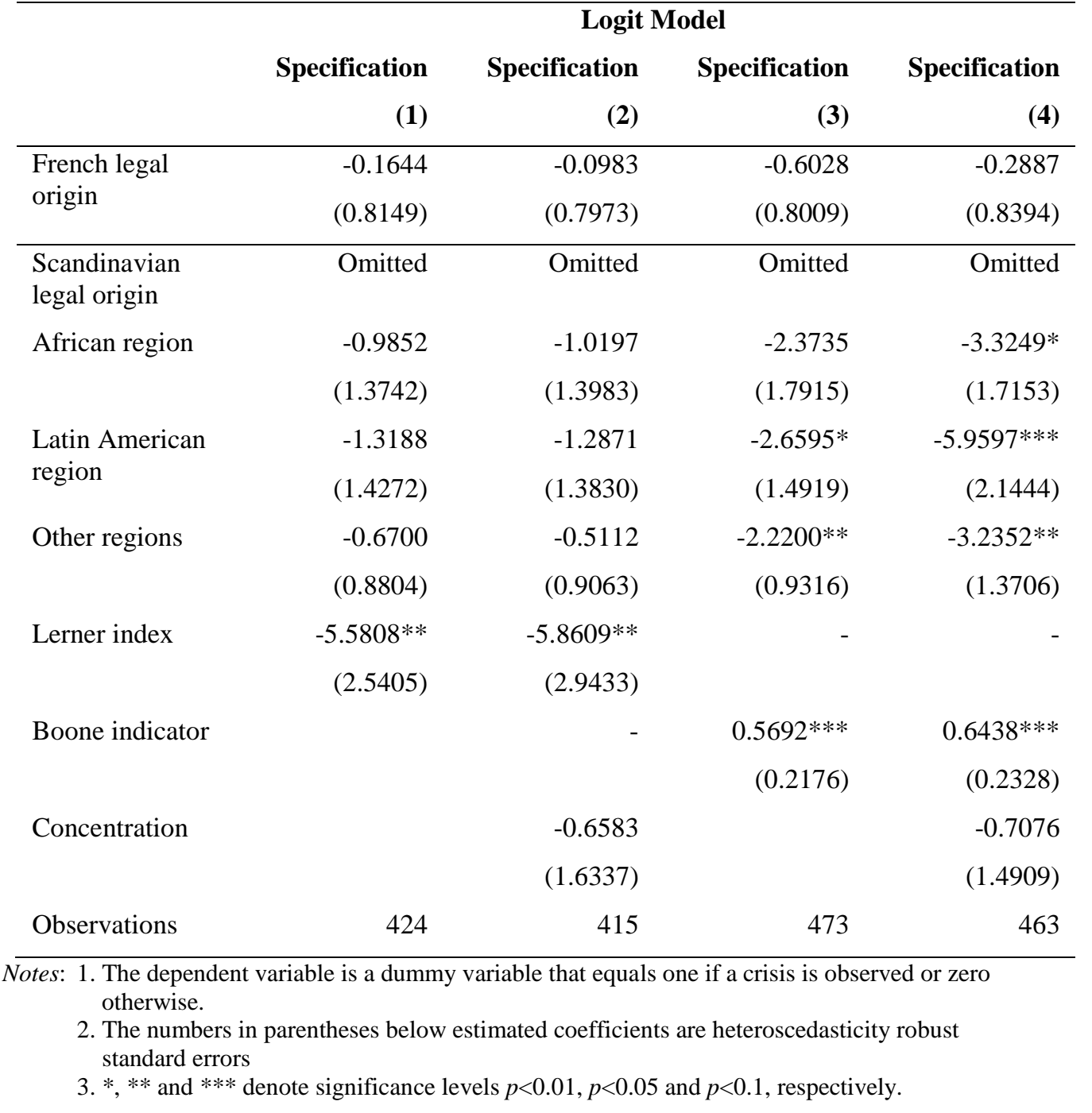

Table 4 reports results based on fractional logistic regression procedure. Columns (1) and (2) estimate specifications with Lerner index and there is a positive association with Z-score. It implies that there is a high probability of default with increasing competition. Lerner index is statistically significant at $1 \%$ level. This finding confirms the results of Beck et al. (2013). In Columns (3) and (4), Boone indicator is negatively associated with Z-score at $1 \%$ significance level. It presents that increasing competition contributes to a low probability of default. This validates the findings of Schaeck and Cihak (2008). As Schaeck and Cihak (2008) suggest, when competition in banking increases soundness and policymakers are responsible to improve regulatory disclosure requirements, increase the market discipline in monitoring to maintain the soundness of the financial system. Concentration ratio is 
statistically insignificant in all estimation specifications. There is no evidence to confirm that bank concentration contributes to fragility or stability in the financial system. The moral hazard index measures generosity of deposit insurance scheme and is positively associated with the Z-score at $1 \%$ significance level. The increased moral hazard index indicates greater stability. When depositors attempt to withdraw their funds all at once, solvent individual banks may be forced into insolvency. Therefore, policies associated with insuring the deposits of banks reduce financial instability (Anginer \& Demirguc-Kunt, 2011; Barth, Caprio, \& Levine, 2013). Real interest rate and inflation increase financial stability and credit growth lowers stability in most regressions. Significant dummies for German, British, and French legal origins enter positively suggesting that low probability of default from countries with German, British, and French legal origins. Regional dummies for African, Latin American, and other regions enter negatively and significantly throughout, indicating a greater chance of default compared to G10 countries.

Table 4: Bank Competition and Inverse Probability of Default

\begin{tabular}{lrrrr}
\hline & & \multicolumn{2}{c}{ Fractional Logistic Model } & \\
& Specification & Specification & Specification & Specification \\
\hline GDP growth & $(\mathbf{1})$ & $(\mathbf{2})$ & $\mathbf{( 3 )}$ & $\mathbf{( 4 )}$ \\
\hline & $(0.0083)$ & $(0.0083)$ & $(0.0067)$ & $(0.0069)$ \\
Real interest & $0.0196 * * *$ & $0.0200 * * *$ & 0.0037 & $0.01437 * * *$ \\
rate & $(0.0030)$ & $(0.0031)$ & $(0.0034)$ & $(0.0041)$ \\
Inflation & $0.0168 * * *$ & $0.0171 * * *$ & 0.0042 & $0.0113 * *$ \\
& $(0.0041)$ & $(0.0041)$ & $(0.0045)$ & $(0.0049)$ \\
Terms of trade & 0.0030 & 0.0030 & 0.0047 & 0.0045 \\
& $(0.0027)$ & $(0.0027)$ & $(0.0030)$ & $(0.0029)$ \\
Credit growth & $-0.1285 *$ & -0.1043 & $-0.2183 * * *$ & $-0.1719 * *$ \\
& $(0.0705)$ & $(0.0741)$ & $(0.0665)$ & $(0.0691)$ \\
Moral hazard & $0.0444 * * *$ & $0.0379 * * *$ & $0.0478 * * *$ & $0.0395 * * *$ \\
index & $(0.0115)$ & $(0.0114)$ & $(0.0125)$ & $(0.0126)$ \\
German legal & & $0.4022 * * *$ & $0.1954 * *$ & $0.2105 * * *$ \\
origin & $0.3870 * * *$ & $(0.0683)$ & $(0.0796)$ & $(0.0751)$ \\
\hline & $(0.0668)$ & & &
\end{tabular}




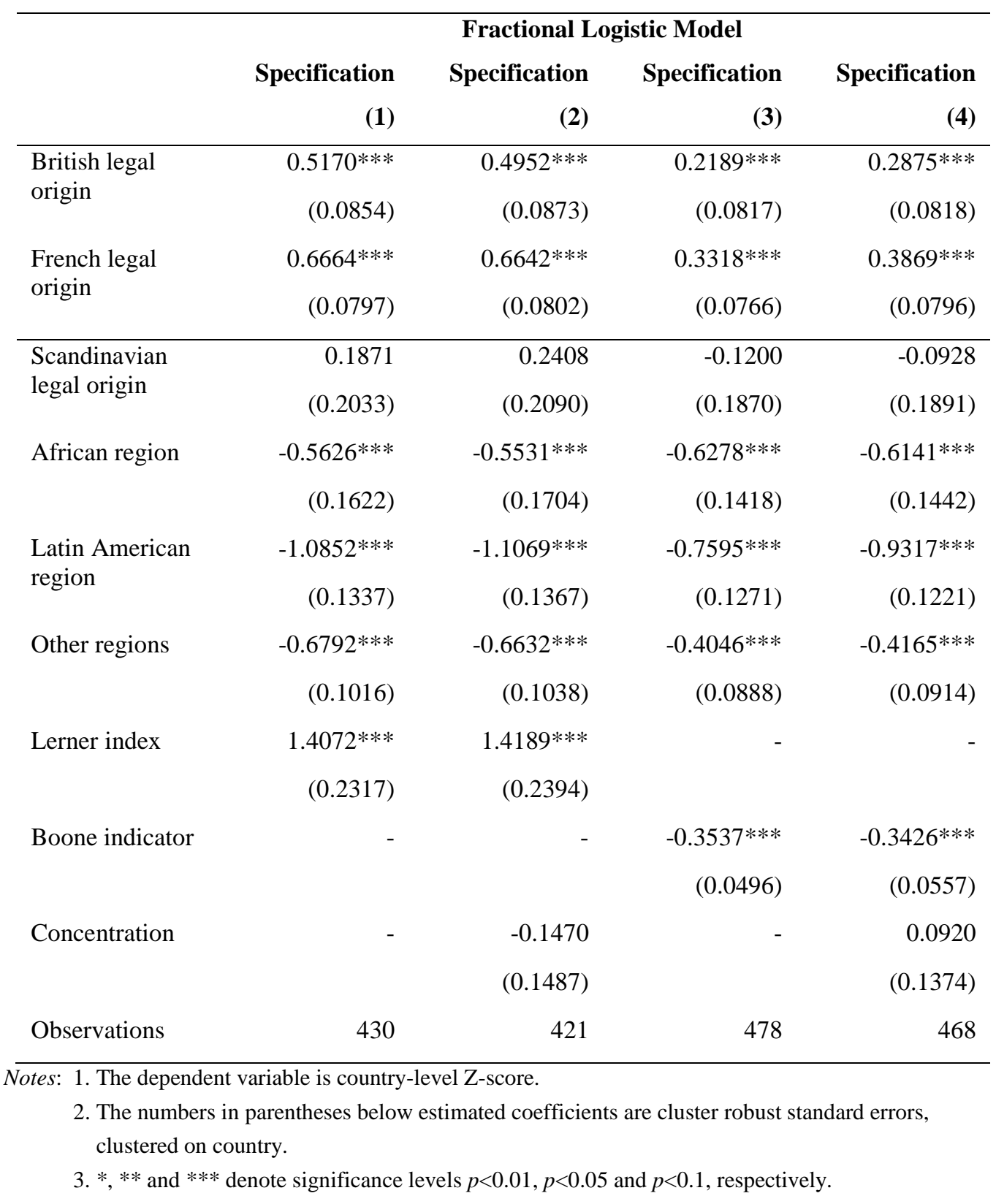

\section{Conclusion}

Identification of causes of financial instability is important to minimise the effect of future financial crisis. Zigraiova and Havranek (2016) find that data, study characteristics, and estimation procedures contribute to observed heterogeneities across studies. This study empirically investigates the findings of Zigraiova and Havranek (2016) using various proxy measures of bank competition, financial 
stability and different estimation methods. Bank competition was measured by using Lerner index and Boone indicator. The updated cross-country systemic banking crises data of Laeven and Valencia (2018) are used as the dependent variable in the duration and logit estimation procedures. The estimation results of duration model and logit model find that Lerner index and Boone indicator act differently. Lerner index supports 'competition-fragility' view and Boone indicator supports 'competitionstability' view. Moreover, this study finds that bank concentration is not a contributing factor to the occurrence of systemic crisis using more recent crisis episodes. It rejects the view that concentrated banking systems are less prone to systemic crisis.

When Z-score is used as the alternative dependent variable, Lerner and Boone indices re-confirm the findings of previous estimation procedures. In summary, the focus of this study is to provide empirical evidence to support the findings of Zigraiova and Havranek (2016) and results confirm that the nature of the relationship between bank competition varies with the use of proxy measures, different systemic crisis events, and methods of estimation. However, the main limitation of the study is that it could not present a final judgement about the effect of bank competition on financial stability and it is an important path for a future research.

In terms of policy implications, the results highlight that there is mixed evidence supporting both 'competition-stability' and 'competition-fragility' hypotheses. Therefore, policymakers are required to implement policies promoting competition, conduct regular monitoring, and increase deposit insurance coverage to protect depositors and to maintain sustainable financial system.

\section{Declaration of Conflict of Interest}

The author declared no potential conflict of interest with respect to the research, authorship, and publication of this article.

\section{References}

Agoraki, M.-E. K., Delis, M. D., \& Pasiouras, F. (2011). Regulations, competition and bank risk-taking in transition countries. Journal of Financial Stability, 7(1), 38-48. doi:10.1016/j.jfs.2009.08.002

Allen, F., \& Gale, D. (2004). Competition and financial stability. Journal of Money, Credit and Banking, 36(3), 453-480. 
Amidu, M., \& Wolfe, S. (2013). Does bank competition and diversification lead to greater stability? Evidence from emerging markets. Review of Development Finance, 3(3), 152-166. doi:10.1016/j.rdf.2013.08.002

Anginer, D., \& Demirguc-Kunt, A. (2011). Has the global banking system become more fragile over time? (Policy Research Working Paper No. 5849).

Bandaranayake, S., Das, K., \& Reed, W. R. (2019). Are competitive banking systems really more stable? Critical Finance Review. Advance online publication. doi:10.1561/104.00000061

Barth, J. R., Caprio, G. J., \& Levine, R. (2013). Bank regulation and supervision in 180 countries from 1999 to 2011 (NBER Working Paper Series No. 18733).

Beck, T. (2008). Bank competition and financial stability: Friends or foes? (World Bank Policy Research Working Paper No. 4656). World Bank

Beck, T., De Jonghe, O., \& Schepens, G. (2013). Bank competition and stability: Cross-country heterogeneity. Journal of Financial Intermediation, 22(2), 218244. doi:10.1016/j.jfi.2012.07.001

Beck, T., Demirgüç-Kunt, A., \& Levine, R. (2003). Bank concentration and crises (NBER Working Paper Series No. 9921).

Beck, T., Demirgüç-Kunt, A., \& Levine, R. (2006). Bank concentration, competition, and crises: First results. Journal of Banking \& Finance, 30(5), 1581-1603. doi:10.1016/j.jbankfin.2005.05.010

Berger, A. N., Demirgüç-Kunt, A., Levine, R., \& Haubrich, J. G. (2004). Bank concentration and competition: An evolution in the making. Journal of Money, Credit and Banking, 36(3), 433-451.

Berger, A. N., Klapper, L. F., \& Turk-Ariss, R. (2009). Bank competition and financial stability. Journal of Financial Services Research, 35(2), 99-118. doi:10.1007/s10693-008-0050-7

Bikker, J. A., \& Haaf, K. (2000). Measures of competition and concentration in the banking industry: A review of the literature. Research Series Supervision (discontinued - De Nederlandsche Bank). Retrieved from https://www.dnb.nl/ en/binaries/ot027_tcm47-146045.pdf

Boone, J. (2008). A new way to measure competition. The Economic Journal, 118(531), 1245-1261. doi:10.1111/j.1468-0297.2008.02168.x

Boyd, J. H., \& De Nicolo, G. (2005). The theory of bank risk taking and competition revisited. Journal of Finance, 60(3), 1329-1343. doi: 10.1111/j.15406261.2005.00763.x

Boyd, J. H., Graham, S. L., \& Hewitt, S. R. (1993). Bank holding company mergers with nonbank financial firms: Effects on the risk of failure. Journal of Banking and Finance, 17, 43-63. doi:10.1016/0378-4266(93)90079-S 
Boyd, J. H., \& Runkle, D. E. (1993). Size and performance of banking firms: Testing the predictions of theory. Journal of Monetary Economics, 31(1), 47-67. doi:10.1016/0304-3932(93)90016-9

Caminal, R., \& Matutes, C. (2002). Market power and banking failures. International Journal of Industrial Organization, 20, 1341-1361. doi:10.1016/S01677187(01)00092-3

Claessens, S., \& Laeven, L. (2004). What drives bank competition? Some international evidence. Journal of Money, Credit, and Banking, 36(3), 563-583. Retrieved from www.jstor.org/stable/3838954

Demirgüç-Kunt, A., \& Detragiache, E. (1998). The determinants of banking crises in developing and developed countries. Internationl Monetray Fund Staff Papers, 45(1), 81-109.

Demirgüç-Kunt, A., \& Detragiache, E. (2002). Does deposit insurance increase banking system stability? An empirical investigation. Journal of Monetary Economics, 49, 1373-1406. doi:10.1016/S0304-3932(02)00171-X

Demirgüç-Kunt, A., \& Detragiache, E. (2005). Cross-country empirical studies of systemic bank distress: A survey. National Institute Economic Review, 192(1), 68-83. doi:10.1177/002795010519200108

Demirgüç-Kunt, A., \& Martínez Pería, M. S. (2010). A framework for analyzing competition in the banking sector:An application to the case of Jordan (The World Bank Policy Research Working Paper No. 5499).

Diallo, B. (2015). Bank competition and crises revisited: New results. Economics Letters, 129, 81-86. doi:10.1016/j.econlet.2015.02.015

Fernandez, R. O., \& Garza-Garciab, J. G. (2012). The relationship between bank competition and financial stability: A case study of the Mexican banking industry (Centre for Global Finance Working Paper No. 03/12).

Fu, X., Lin, Y., \& Molyneux, P. (2014). Bank competition and financial stability in Asia Pacific. Journal of Banking \& Finance, 38, 64-77. doi:10.1016/ j.jbankfin.2013.09.012

Goetz, M. (2016). Competition and bank stability (CFS Working Paper No. 559). Germany.

Jeon, J. Q., \& Lim, K. K. (2013). Bank competition and financial stability: A comparison of commercial banks and mutual savings banks in Korea. PacificBasin Finance Journal, 25, 253-272. doi:10.1016/j.pacfin.2013.10.003

Keeley, M. C. (1990). Deposit insurance, risk, and market power in banking. The American Economic Review, 80(5), 1183-1200.

La-Porta, R., Lopez-de-Silanes, F., \& Shleifer, A. (1998). Law and finance. Journal of Political Economy, 106, 1113-1155. doi:10.1086/250042 
Laeven, L., \& Valencia, F. (2008). Systemic banking crises: A new database (IMF Working Paper No. 08/224).

Laeven, L., \& Valencia, F. (2012). Systemic banking crises database : An update (IMF Working Paper No. 12/163).

Laeven, L., \& Valencia, F. (2018). Systemic banking crises revisited (IMF Working Paper No.18/206).

Leon, F. (2015). Does bank competition alleviate credit constraints in developing countries? Journal of Banking \& Finance, 57, 130-142. doi:10.1016/ j.jbankfin.2015.04.005

Liu, H., Molyneux, P., \& Nguyen, L. H. (2012). Competition and risk in South East Asian commercial banking. Applied Economics, 44(28), 3627-3644. doi:10.1080/00036846.2011.579066

Liu, H., Molyneux, P., \& Wilson, J. O. S. (2013). Competition and stability in European banking: A regional analysis. The Manchester School, 81(2), 176-201. doi:10.1111/j.1467-9957.2011.02285.x

Marcus, A. J. (1984). Deregulation and bank financial policy. Journal of Banking \& Finance, 8(4), 557-565. doi:10.1016/S0378-4266(84)80046-1

Oliver, A. M., Fumás, V. S., \& Saurina, J. (2006). Risk premium and market power in credit markets. Economics Letters, 93(3), 450-456. doi:10.1016/ j.econlet.2006.06.021

Papke, L. E., \& Wooldridge, J. M. (1996). Econometric methods for fractional response variables with an application to $401(\mathrm{k})$ plan participation rates. Journal of Applied Econometrics, 11, 619-632. doi:10.1002/(SICI)1099-1255(199611) 11:6<619::AID-JAE418>3.0.CO;2-1

Schaeck, K., \& Cihak, M. (2008). How does competition affect efficiency and soundness in banking? New empirical evidence (ECB Working Paper Series No. 932).

Schaeck, K., \& Cihak, M. (2010). Competition, efficiency, and soundness in banking: An industrial organization perspective. (European Banking Center Discussion Paper No. 2010-20S). doi:10.2139/ssrn.1635245

Schaeck, K., \& Cihak, M. (2014). Competition, efficiency, and stability in banking. Financial Management, 43(1), 215-241. doi:10.1111/fima.12010

Schaeck, K., Cihak, M., \& Wolfe, S. (2009). Are competitive banking systems more stable? Journal of Money, Credit and Banking, 41(4), 711-734. doi:10.1111/j.1538-4616.2009.00228.x

Spierdijk, L., \& Zaouras, M. (2016). The Lerner index and revenue maximization. Applied Economics Letters, 24(15), 1075-1079. doi:10.1080/1350485 $\underline{1.2016 .1254333}$ 
Tabak, B. M., Fazio, D. M., \& Cajueiro, D. O. (2012). The relationship between banking market competition and risk-taking: Do size and capitalization matter? Journal of Banking \& Finance, 36(12), 3366-3381. doi:10.1016/ j.jbankfin.2012.07.022

Van Leuvensteijn, M., Bikker, J. A., van Rixtel, A. A. R. J. M., \& Sørensen, C. K. (2011). A new approach to measuring competition in the loan markets of the euro area. Applied Economics, 43(23), 3155-3167. doi:10.1080/00036840903493234

Yeyati, E. L., \& Micco, A. (2007). Concentration and foreign penetration in Latin American banking sectors: Impact on competition and risk. Journal of Banking \& Finance, 31(6), 1633-1647. doi:10.1016/j.jbankfin.2006.11.003

Zigraiova, D., \& Havranek, T. (2016). Bank competition and financial stability: Much ado about nothing? Journal of Economic Surveys, 30(5), 944-981. doi:10.1111/joes.12131

\section{Appendix 1}

\section{Description of Variables}

\begin{tabular}{ll}
\hline Variable & Definition \\
\hline Z-score & It measures the probability of default of a country's banking \\
system. Z-score compares capitalization and returns with the \\
volatility of those returns. \\
This is a measure of market power of the bank. It is the \\
difference between output prices and marginal costs. Prices \\
are calculated as total bank revenue over assets, whereas \\
marginal costs are calculated from a translog cost function \\
with respect to output costs. Higher values of the Lerner index \\
indicate less bank competition. This database uses the \\
methodology of Demirgüç-Kunt and Martínez Pería (2010) to \\
calculate the country-level Lerner index. \\
This is a measure of degree of competition, calculated as the \\
elasticity of profits to marginal costs. To estimate the \\
elasticity, the log of profits is regressed on the log of average \\
costs. The estimated coefficient is the Boone indicator. \\
According to the interpretation of the Boone indicator, higher \\
profits are achieved by more-efficient banks. Hence, the more \\
negative the Boone indicator, the higher the degree of
\end{tabular}




\begin{tabular}{ll}
\hline Variable Definition \\
\\
\hline $\begin{array}{l}\text { competition. This database uses the methodology of Schaeck } \\
\text { and Cihák (2010) to calculate the country-level Boone } \\
\text { indicator. }\end{array}$ \\
\hline
\end{tabular}

GDP Growth

Inflation

Real interest rate

Credit growth

Terms of trade

Moral Hazard
Rate of growth of the gross domestic production (GDP) is the annual percentage growth rate of GDP at market prices and it is lagged by one year.

Rate of change of the GDP deflator.

Real interest rate is the lending interest rate adjusted for inflation as measured by the GDP deflator.

The annual percentage growth of domestic credit to the private sector, adjusted for inflation with GDP deflator.

Change in the net barter terms of trade

Indicator of generosity of design features of deposit insurance schemes. It is calculated as the first principal component of the following design features: no co-insurance, unlimited explicit coverage, explicit coverage limit, coverage of foreign currency and interbank deposits (Demirgüç-Kunt \& Detragiache, 2002).

Concentration

German legal origin

Scandinavian legal origin

British legal origin

French legal origin

African

Latin American

Other
Percentage of total assets held by the three largest banking institutions in a country (averaged over the sampling period). system is of German origin or zero otherwise.

Dummy variable that takes the value one if the country's legal system is of Scandinavian origin or zero otherwise.

Dummy variable that takes the value one if the country's legal system is of British origin or zero otherwise.

Dummy variable that takes the value one if the country's legal system is of French origin or zero otherwise.

Dummy variables that take on the value one if the country belongs to African region or zero otherwise.

Dummy variables that take on the value one if the country belongs to Latin American region or zero otherwise.

Dummy variables that take on the value one if the country belongs to any other region/classification other than African, Latin American, or G10 or zero otherwise.
Dummy variable that takes the value one if the country's legal 


\section{Appendix 2}

\section{Pairwise Correlation}

\begin{tabular}{|c|c|c|c|c|c|c|c|c|c|c|}
\hline & $\begin{array}{l}\text { GDP } \\
\text { growth }\end{array}$ & Inflation & $\begin{array}{l}\text { Real } \\
\text { interest } \\
\text { rate }\end{array}$ & TOT & $\begin{array}{l}\text { Credit } \\
\text { growth }\end{array}$ & $\begin{array}{l}\text { Moral } \\
\text { hazard }\end{array}$ & Lerner & Concentration & Boone & Z-score \\
\hline GDP growth & 1.0000 & & & & & & & & & \\
\hline Inflation & -0.0648 & 1.0000 & & & & & & & & \\
\hline $\begin{array}{l}\text { Real interest } \\
\text { rate }\end{array}$ & -0.1766 & -0.0821 & 1.0000 & & & & & & & \\
\hline TOT & 0.0595 & 0.0120 & -0.0580 & 1.0000 & & & & & & \\
\hline Credit growth & -0.0244 & -0.0663 & -0.0823 & -0.1087 & 1.0000 & & & & & \\
\hline Moral hazard & -0.0101 & -0.1516 & -0.0097 & -0.0216 & 0.1549 & 1.0000 & & & & \\
\hline Lerner & 0.1227 & 0.1287 & -0.1845 & 0.0801 & -0.0978 & 0.0146 & 1.0000 & & & \\
\hline Concentration & -0.0667 & 0.0444 & 0.0527 & -0.0368 & -0.0500 & 0.0189 & 0.0157 & 1.0000 & & \\
\hline Boone & -0.0054 & 0.0412 & -0.0145 & 0.0266 & -0.0303 & 0.0349 & 0.0835 & 0.1398 & 1.0000 & \\
\hline Z-score & -0.0207 & -0.0270 & -0.0557 & 0.0067 & 0.0664 & 0.2660 & 0.1109 & -0.0214 & -0.2075 & 1.0000 \\
\hline
\end{tabular}

